\title{
PENINGKATAN KUALITAS KESEHATAN MASYARAKAT UNTUK PENCEGAHAN PENYEBARAN COVID-19 DI MASA PANDEMI
}

\author{
Zainal Abidin*, Afni Yanti, Indra Zulfayanto, Muhammad Rasid, Nining Ismiyanti, Nur \\ Fitrianingsi, Sinta Dwiyana, Ummi Hasanah Nabila, Yuli Paramita, Zakiah Koima \\ Bilkist \\ Fakultas Keguruan dan Ilmu Pendidikan, Universitas Islam Malang
}

Korespondensi email: zainal_abid@unisma.ac.id

\begin{abstract}
ABSTRAK
Keputusan Menteri Kesehatan Republik Indoesia Nomor HK.01.07/Menkes413/2020 Tentang Pedoman Pencegahan dan Pengendalian Coronavirus Disease 2019 (Covid-19), WHO telah menetapkan bahwa coronavirus merupakan global pandemic. Sejak kasus pertama di Indonesia, yaitu pada tanggal 2 maret 2020 yang hingga saat ini penyebarannya sangatlah pesat. Dengan pesatnya penyebaran covid-19 sangat meresahkan warga. Kegiatan pengabdian ini bertujuan untuk menjelaskan langkah-langkah untuk mencegah atau mengurangi penyebaran covid-19 di Indonesia. Langkah yang dilakukan dalam pencegahan atau pengurangan penyebaran covid-19 yaitu dengan menempelkan poster penerapan 5M, penyebaran video yang berisi ajakan menerapkan 5M, pembagian handsanitizer, sosialisasi secara door to door dan sosialisasi virtual melalui aplikasi zoom meeting. Dengan melaksanakan program tersebut dapat meningkatkan kesadaran serta pengetahuan kepada masyarakat dalam penularan covid-19 sehingga penyebaran virus covid-19 ini dapat berkurang dan segera berakhir.
\end{abstract}

Kata Kunci: kualitas kesehatan; pencegahan; penerapan 5M; covid-19.

\section{PENDAHULUAN}

Virus corona merupakan suatu kelompok virus yang menyerang saluran pernafasan. Virus ini menyebabkan infeksi saluran pernafasan pada manusia seperti batuk, pilek, hingga yang lebih serius seperti Middle East Respiratory Syndrome (MERS) dan Severe Acute Respiratory Syndrome (SARS) (Guan, dkk 2020). Virus corona yang menggemparkan dunia ini merupakan jenis baru yang diberi nama Severe Acute Respiratory Syndrome Coronavirus2 (SARS-CoV-2) oleh World Health Organizatio (WHO) dan nama penyakitnya disebut Coronavirus Disease 2019 (COVID-19) (Yuliana, 2020). Sampai saat ini laju persebaran Corona virus Disease-2019 (COVID-19) meningkat semakin cepat melalui tetesan air liur atau keluar dari hidung ketika orang yang terinfeksi batuk atau bersin secara langsung.

Dalam menghadapi masa pandemi COVID-19 ini, menurut Mardiyani et al. (2020) mendorong setiap individu untuk menjaga kesehatan diri sendiri dan melindungi orang lain, yaitu dengan cara: 1) sering mencuci tangan dengan air dan sabun atau menggunakan gel pembersih tangan, 2) menjaga jarak sosial, 3) menghindari menyentuh mata, hidung dan mulut, 4) melakukan kebersihan pernapasan (menutupi mulut dan hidung dengan siku atau tisu yang tertekuk saat batuk atau bersin, kemudian segera membuang tisu bekas), 5) mencari perawatan medis lebih awal jika mengalami demam, batuk dan kesulitan bernapas, 
dan 6) tetap terinformasi dan mengikuti protokol kesehatan (WHO, 2020). Selain itu, pemerintah di negara kita juga sudah melakukan berbagai upaya, yaitu pencegahan dan penanggulangan penyebaran COVID-19 yang sangat cepat ini dalam berbagai aspek kehidupan, mulai dari bidang pendidikan, sosial masyarakat, dan kesehatan. Di bidang kesehatan, pemerintah telah memberikan edukasi kepada masyarakat terkait pentingnya hidup bersih dan sehat, perlunya mengenakan masker saat di luar rumah, pelaksanaan karantina mandiri untuk orang-orang yang memiliki risiko tinggi, serta berbagai pedoman yang bertujuan untuk mencegah penularan COVID-19 (Telaumbanua, 2020).

Berbagai upaya telah dilakukan oleh pemerintah dalam menanggulangi penyebaran COVID-19, namun penambahan kasus positif COVID-19 di Indonesia semakin terus bertambah. Hal ini dapat disebabkan karena kurangnya pengetahuan terhadap bahaya COVID-19 yang mengakibatkan kurangnya kesadaran masyarakat sehingga penanganan (pencegahan bagi yang tidak terinfeksi dan/atau pengobatan terhadap yang terkena wabah) kurang terlaksana dengan baik dalam sistem pemerintahan, dari daerah pusat hingga bagian daerah paling bawah, yaitu desa (Martino et al., 2018).

Pengabdian masyarakat merupakan bagian tak terpisahkan dari filosofi dasar Tri Dharma Perguruan Tinggi yang implementasinya berbasiskan penelitian maupun pembelajaran (Hendayana, 2020). Oleh karena itu, pada masa-masa seperti inilah hati nurani civitas akdemika Universitas Islam Malang sebagai institusi yang tumbuh dan berkembang di tengah masyarakat merasa terpanggil, yaitu dengan mengadakan program pengabdian masyarakat melalui kegiatan Kandidat Sarjana Mengabdi Tematik (KSM-T).

Berdasarkan latar belakang di atas, dengan adanya program KSM-T, Dosen Pembimbing Lapangan (DPL) besama mahasiswa KSM kelompok 59 tertarik untuk melakukan kegiatan edukasi terkait pencegahan COVID-19 dengan cara penyebaran poster, pembuatan dan penyebaran video kreatif, dan Sosialisasi secara daring melalui via Zoom untuk meningkatkan kesadaran dan kualitas kesehatan masyarakat di masa pandemi COVID-19.

\section{METODE}

Metode pelaksanaan kegiatan pengabdian kepada masyarakat yaitu peningkatan kualitas kesehatan masyarakat melalui sosialisasi pencegahan covid-19 dengan memperhatikan protokol kesehatan dan pembuatan serta pembagian hand sanitizer. Dalam melakukan kegiatan pengabdian pada masyarakat ini dilakukan kegiatan-kegiatan antara lain: (1) Penempelan poster pencegahan penularan covid-19 ; (2) Penyebaran video kreatif di media sosial terkait pencegahan covid-19 seperti whatsapp, facebook dan instagram; (3) Pembuatan dan pembagian hand sanitizer kepada masyarakat; (4) Sosialisasi yang dilakukan dengan cara door to door ke rumah warga; (5) Penyuluhan yang dilaksanakan menggunakan media sosial zoom sebagai sarana mengedukasi masyarakat dalam mencegah dan memutus rantai penyebaran wabah covid 19 yang dibuka untuk peserta secara umum.

Lokasi kegiatan pengabdian antara lain di (1) Desa Bocek, Kec. Karangploso, Kab. Malang. Jawa Timur, (2) Desa Baru Tahan, Kec. Moyo Utara. Kab. Sumbawa, Nusa Tenggara Barat, (3) Desa Semanggis Raya, Kec. Mukok, Kab. Sanggau, Kalimantan Barat, (4) Desa Tara Manu, Kec. Wanokaka, Kab. Sumba Barat, Nusa Tenggara Timur, (5) Desa Kaliacar, Kec. Gading, Probolinggo, Jawa Timur, (6) Desa Tabiku, Kec. Seruyan Raya, Kab. Seruyan, Kalimantan Tengah.

\section{HASIL DAN PEMBAHASAN}

Untuk meningkatkan kualitas kesehatan masyarakat di masa pandemi covid-19 ini dapat dilakukan dengan beberapa cara. Pertama, penempelan poster. Poster ini sendiri 
berisi cara-cara pencegahan covid-19, penempelan poster ini dilakukan di tempat-tempat yang biasanya masyarakat berkumpul, seperti tempat kerja, tempat wisata, warung, pasar dan lain sebagainya. Penempelan poster ini juga dilakukan di beberapa daerah peserta KSM kelompok 59, salah satunya dilakukan di desa Semanggis Raya, Kalimantan Barat.

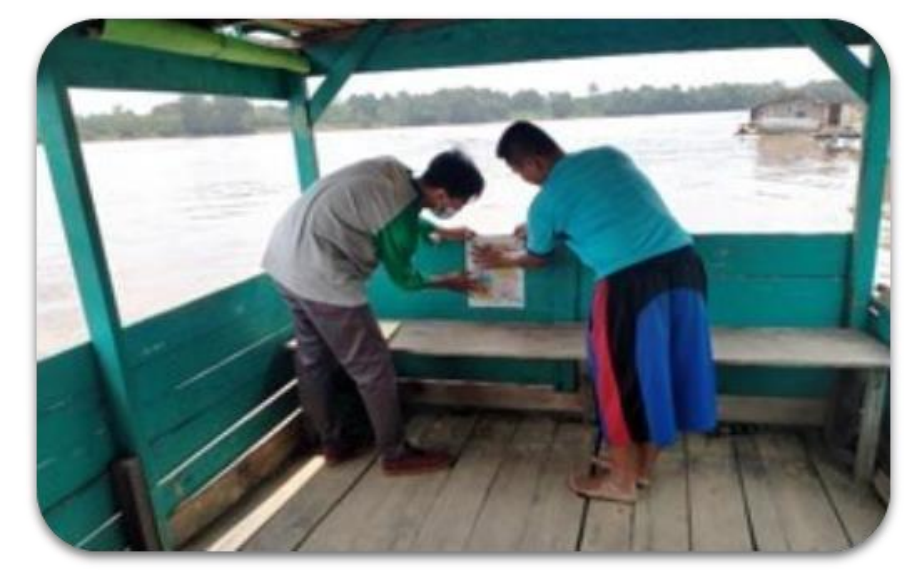

Gambar 1. Penempelan Poster Covid-19

Kedua, penyebaran video kreatif di media sosial terkait pencegahan covid-19. Penyebaran video dilakukan di media sosial yang umum digunakan masyarakat seperti whatsapp, facebook dan instagram.

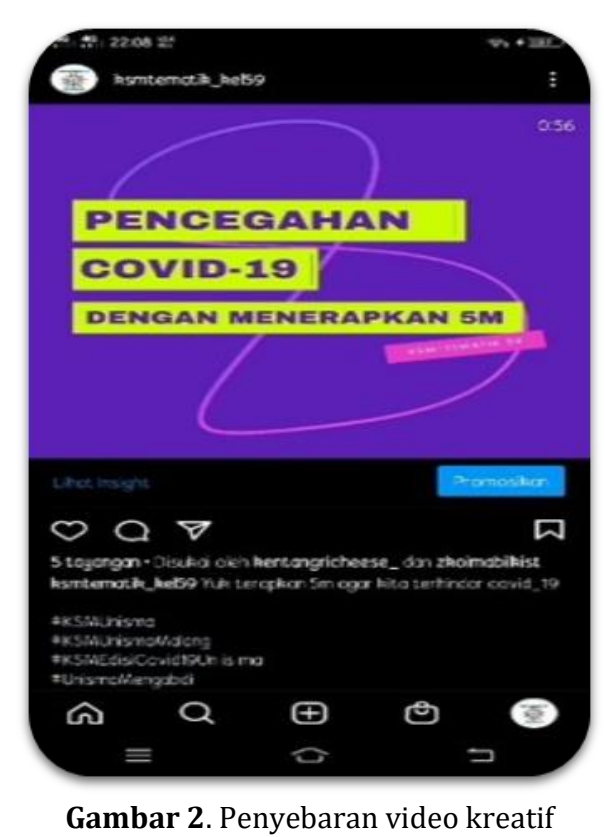

Ketiga, pembuatan dan pembagian hand sanitizer kepada masyarakat. Kegiatan ketiga ini dilakukan di desa Kaliacar, Probolinggo yang bertujuan agar masyarakat tetap sadar akan kebersihan, terutama kebersihan tangan. Karena kebersihan sangat berpengaruh dalam mencegah agar tidak terpapar virus covid-19. Kebersihan tangan bisa dilakukan dengan mencuci tangan menggunakan sabun atau hand sanitizer. 
Abidin, Z., et al.

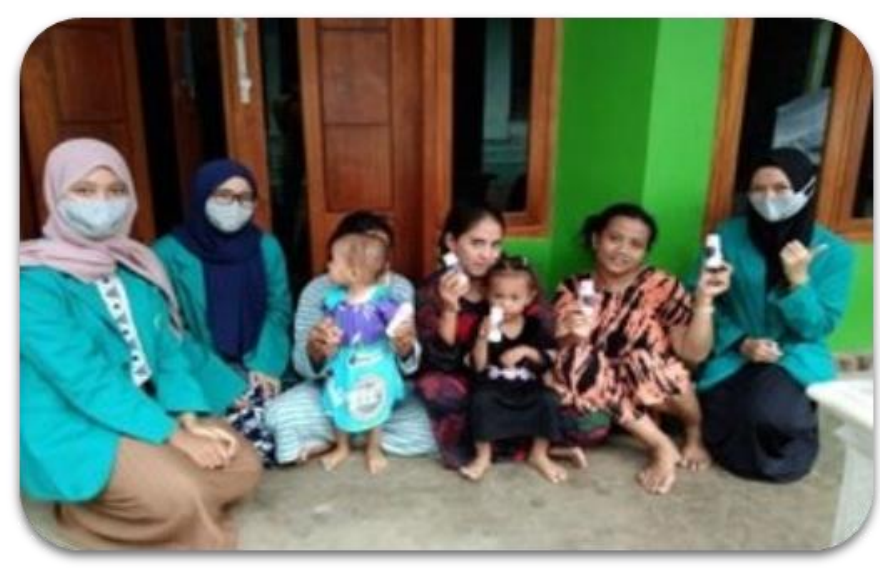

Gambar 3. Pembagian hand sanitizer

Keempat, sosialisasi yang dilakukan dengan cara door to door ke rumah warga. Sosialisasi yang dilakukan tersebut tidak jauh berbeda dari kegiatan yang lainnya yaitu menjelaskan tentang cara pencegahan covid-19. Selain itu, sosialisasi ini juga bertujuan agar masyarakat lebih memahami dan sadar akan bahaya serta cara agar terhindari dari virus tersebut. Kegiatan sosialisasi ini dilakukan di salah satu daerah peserta KSM kelompok 59 yaitu di desa Baru Tahan, Nusa Tenggara Barat.

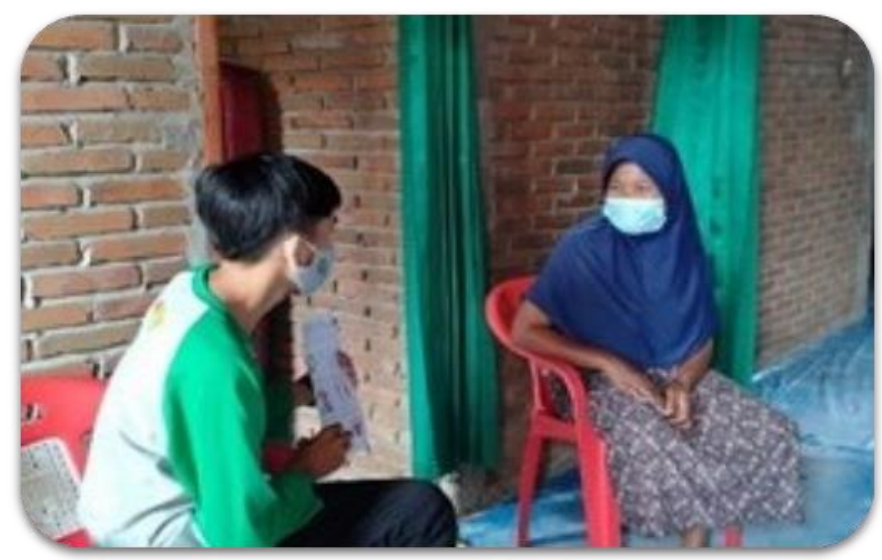

Gambar 4. Sosialisasi door to door

Kelima, sosialisasi yang dilakukan via aplikasi zoom meeting dengan cara mengajak tetangga, teman, keluarga, serta kerabat.

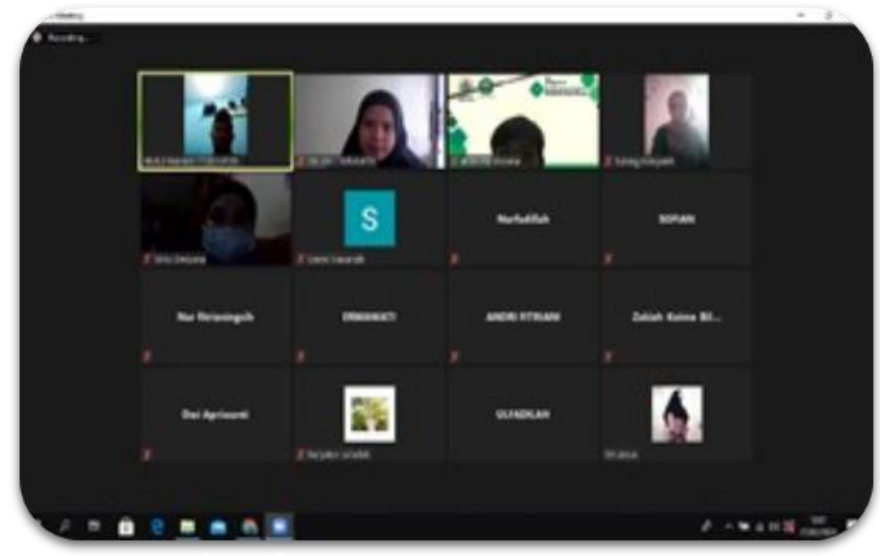

Gambar 5. Sosialisasi via aplikasi zoom meeting 


\section{KESIMPULAN}

Pengabdian kepada masyarakat tentang peningkatkan kualitas kesehatan masyarakat di masa pandemi covid-19 telah dilaksanakan dan mendapat respon positif di mana terlihat dari reponden masyarakat yang ikut terlibat aktif dalam peningkatan kualitas kesehatan masyarakat melalui sosialisasi pencegahan covid-19 serta penempelan poster protokol kesehatan. Kegiatan pengabdian kepada masyarakat tentang peningkatkan kualitas kesehatan masyarakat di masa pandemi covid-19 dapat dilakukan sebagai berikut:

1. Penempelan poster. Poster ini sendiri berisi cara-cara pencegahan covid-19, penempelan poster ini dilakukan di tempat-tempat yang biasanya masyarakat berkumpul, seperti tempat kerja, tempat wisata, warung, pasar dan lain sebagainya.

2. Penyebaran video kreatif di media sosial terkait pencegahan covid-19. Penyebaran video dilakukan di media sosial yang umum digunakan masyarakat seperti whatsapp, facebook dan instagram.

3. Pembuatan dan pembagian hand sanitizer kepada masyarakat. Kegiatan ketiga ini dilakukan di desa Kaliacar, Probolinggo yang bertujuan agar masyarakat tetap sadar akan kebersihan, terutama kebersihan tangan. Karena kebersihan sangat berpengaruh dalam mencegah agar tidak terpapar virus covid-19.

4. Sosialisasi yang dilakukan dengan cara door to door ke rumah warga. Sosialisasi yang dilakukan tersebut tidak jauh berbeda dari kegiatan yang lainnya yaitu menjelaskan tentang cara pencegahan covid-19. Selain itu, sosialisasi ini juga bertujuan agar masyarakat lebih memahami dan sadar akan bahaya serta cara agar terhindari dari virus tersebut.

5. Penyuluhan yang dilaksanakan menggunakan media sosial zoom sebagai sarana mengedukasi masyarakat dalam mencegah dan memutus rantai penyebaran wabah covid 19, yang dibuka untuk umum sebagai pesertanya. Tujuannya memberikan pemahaman bagi masyarakat luas mengenai bahaya dan pencegahan virus covid 19 .

Kegiatan pengabdian kepada masyarakat ini telah meningkatkan kesadaran serta pengetahuan kepada masyarakat dalam penularan covid-19 sehingga penyebaran virus covid-19 ini dapat berkurang dan segera berakhir.

\section{UCAPAN TERIMA KASIH}

Ucapan terima kasih bisa disampaikan kepada civitas akademika UNISMA khususnya LPPM yang telah memberikan kesempatan kepada kami untuk melaksanakan kegiatan KSMTematik. Terimakasih kepada seluruh anggota peserta KSM atas kerjasamanya dalam pelaksanaan KSM-Tematik berbasis domisili.

\section{DAFTAR RUJUKAN}

Telaumbanua, D. 2020. Urgensi Pembentukan Aturan Terkait Pencegahan Covid-19 di Indonesia. QALAMUNA: Jurnal Pendidikan, Sosial, Dan Agama, 12(01), 59-70. https://doi.org/10.37680/qalamuna.v12i01.290

Mardiyani, S. A., Hidayatullah, M., Sofa, M. Z., Delphia, P., Muhamad, H., Nugraha, M. A. T., Pirain, A. S., Yaqin, M. A., Sukari, S., Bajuber, H. A. A., Mulya, M. B. B., Abbas, T. B., Azrina, S. N., \& Syahputra, V. T. (2020). Edukasi Praktek Cuci Tangan Standar WHO dan Peduli Lingkungan. Jurnal Pembelajaran Pemberdayaan Masyarakat (JP2M), 1(2), 85-91. https://doi.org/10.33474/jp2m.v1i2.6531

Yuliana, Y. 2020. Corona virus diseases (Covid-19): Sebuah tinjauan literatur. Wellness And Healthy Magazine, 2(1), 187-192. https://doi.org/10.30604/well.95212020

Martino, Y. A., Sulistiowati, E., \& Purnomo, Y. (2018). Model Pemberdayaan Santri Ponpes AlHidayah Batu Alang Sebagai Kader Kesehatan Berbasis Terapi Herbal. Jurnal Inovasi 
Hasil Pengabdian Masyarakat (JIPEMAS), 1(2), 86-93. https://doi.org/10.33474/jipemas.v1i2.1514

Guan, W, dkk. 2020. Clinical Characteristics of Coronavirus Disease 2019 in China. New England Journal of Medicine, 382(18), 1708-1720. https://doi.org/10.1056/nejmoa2002032

KemenkesRI. 2020. Keputusan Menteri Kesehatan Republik Indonesia Nomor HK.01.07/MenKes/413/2020 Tentang Pedoman Pencegahan dan Pengendalian Corona Virus Disease 2019 (Covid-19). MenKes/413/2020, 2019, 1-207. https://covid19.go.id/storage/app/media/Regulasi/KMK No. HK.01.07-MENKES413-2020 ttg Pedoman Pencegahan dan Pengendalian COVID-19.pdf

World Health Organization (WHO). 2020. WHO Announces COVID-19 Outbreak a Pandemic. World Health Organzation Regional Office for Europe. Online. https://www.euro.who.int/en/health-topics/health-emergencies/coronaviruscovid-19/news/news/2020/3/who-announces-covid-19-outbreak-a-pandemic 